\title{
Constructed wetland systems vegetated with different plants applied to the treatment of tannery wastewater
}

\author{
Cristina S.C. Calheiros, António O.S.S. Rangel, Paula M.L. Castro*
}

Escola Superior de Biotecnologia, Universidade Católica Portuguesa, Rua Dr. António Bernardino de Almeida, 4200-072 Porto, Portugal

\author{
Keywords: \\ Constructed wetlands \\ Phytoremediation \\ Tannery wastewater \\ Horizontal subsurface flow \\ Phragmites australis \\ Typha latifolia
}

\begin{abstract}
A B S T R A C T
Wastewaters from leather processing are very complex and lead to water pollution if discharged untreated, especially due to its high organic loading. In this study the survival of different plant species in subsurface horizontal flow constructed wetlands receiving tannery wastewater was investigated. Five pilot units were vegetated with Canna indica, Typha latifolia, Phragmites australis, Stenotaphrum secundatum and Iris pseudacorus, and a sixth unit was left as an unvegetated control. The treatment performance of the systems under two different hydraulic loading rates, 3 and $6 \mathrm{~cm} \mathrm{~d}^{-1}$, was assessed. COD was reduced by $41-73 \%$ for an inlet organic loading varying between 332 and $1602 \mathrm{~kg} \mathrm{ha}^{-1} \mathrm{~d}^{-1}$ and $\mathrm{BOD}_{5}$ was reduced by $41-58 \%$ for an inlet organic loading varying between 218 and $780 \mathrm{~kg} \mathrm{ha}^{-1} \mathrm{~d}^{-1}$. Nutrient removal occurred to lower extents. Phragmites australis and Typha latifolia were the only plants that were able to establish successfully. Despite the high removal of organic content from the influent wastewater, during 17 months of operation, no significant differences in performance were observed between units.
\end{abstract}

\section{Introduction}

Constructed wetlands (CWs) can be used for primary, secondary and tertiary treatment of municipal or domestic wastewaters, stormwater, agricultural and industrial wastewaters such as landfill leachate, petrochemicals, food wastes, pulp and paper and mining, usually combined with an adequate pre-treatment (Kadlec et al., 2000). Although they are widely used for municipal wastewater, the application to industrial wastewater has to be carefully analyzed since its composition is frequently highly variable and the treatment needs are not the same. However, the use of CWs for the treatment of industrial wastewaters has increased over the past ten years (Korkusuz, 2005).

The discharge of tannery wastewaters can cause severe environmental problems due to its high chemical oxygen demand (COD) level and, sometimes, high chromium con- centration and deep color content (Song et al., 2000). The effluent treatment systems for the tannery industry experience frequent problems due to the fact that they are often working over the capacity due to poor design, or to increases in production. In these situations, a CW can be potentially used to enhance the overall biological performance (Daniels, $2001 b$ ), or can be an alternative to the conventional biological treatment (Daniels, 2001a; Kucuk et al., 2003). However, no detailed studies on the treatment of tannery wastewater using CWs are known in the literature.

The choice of plants is an important issue in CWs, as they must survive the potential toxic effects of the wastewater and its variability. The most widely used CWs design in Europe is the horizontal subsurface flow system vegetated with the common reed (Phragmites australis) (Vymazal, 2005), although other plant species, such as cattails (Typha spp.) bulrushes (Scipus spp.) and reed canarygrass (Phalaris arundinacea) have

\footnotetext{
*Corresponding author. Tel.: +351 22 5580059; fax: +351225090351.

E-mail addresses: mccalheiros@mail.esb.ucp.pt (C.S.C. Calheiros), aorangel@esb.ucp.pt (A.O.S.S. Rangel), plcastro@esb.ucp.pt (P.M.L. Castro)
} 
been used for both domestic and industrial wastewater treatment (Mbuligwe, 2005; Vymazal, 2005; Vymazal and Krőpfelová, 2005; Shepherd et al., 2001). In Portugal, the main macrophyte species used in CWs are P. australis, Iris pseudacorus (yellow iris) and Cyperus spp. In some systems, Juncus effuses (soft rush), other Juncus spp., and Scirpus spp. (bulrushes) are also found to establish spontaneously (Korkusuz, 2005).

The present study aimed at assessing the use of different plant species in CWs receiving wastewater from a tannery production plant. Six pilot units, with horizontal subsurface flow, were evaluated for a period of 17 months in terms of treatment performance and plant survival when subject to two different hydraulic loadings rates (HLRs).

\section{Methods}

\section{Wetland site}

The experimental pilot units were located at a leather company in the north of Portugal, and placed after a primary treatment of the effluent. This company has only the posttanning and finishing operations, although in a complete productive cycle other operations are included, such as hide and skin storage, beamhouse, deliming, bating, pickling and tanning.

\section{Wastewater sampling and analysis}

The tannery wastewater to be applied to the pilot units was characterized over a one-year period. The following parameters were determined, based on standard methods (APHA, 1998): $\mathrm{pH}$ (Potentiometric Method), chemical oxygen demand (COD; Closed Reflux, Colorimetric Method), biochemical oxygen demand $\left(\mathrm{BOD}_{5}\right.$; 5-Day $\mathrm{BOD}$ Test), total suspended solids (TSS; Total Solids Dried at $103-105^{\circ} \mathrm{C}$ Method), Kjeldahl nitrogen (TKN; Kjeldahl Method), nitrate $\left(\mathrm{NO}_{3}^{-}\right.$; Nitrate Electrode Method), ammonia ( $\mathrm{NH}_{3}$; Phenate Method), total phosphorus (Total P; Manual Digestion and Flow Injection Analysis for Total Phosphorus), total chromium (Total Cr; Nitric Acid Digestion followed by the Colorimetric Method) and hexavalent chromium (Cr VI; Colorimetric Method). The analyses were done immediately after sample collection, otherwise were properly stored.

\section{Constructed wetland pilot units}

Five parallel pilot units were established with five different plant species-Canna indica, T. latifolia, P. australis, Stenotaphrum secundatum and I. pseudacorus - and filled with a substrate composed of light expanded clay (Filtralite ${ }^{\circledR}$ MR 3-8, maxit Group, Portugal). Another pilot unit was filled with the same substrate but was kept without plants. The characteristic size, $d_{c}$, of the substrate was between 3 and $8 \mathrm{~mm}$, according to the technical description from the supplier company. The $\mathrm{pH}$ of the substrate was determined based on Houba et al. (1995).

The structure of the units was made of propylene with the following design characteristics: surface area of the bed, $A=1.2 \mathrm{~m}^{2}$, effective depth of the substrate, $h=0.60 \mathrm{~m}$ and average depth of liquid in the bed, $h_{0}=0.55 \mathrm{~m}$. Near the wastewater inflow and outflow of the beds a layer of coarse rock was put in place in order to facilitate the distribution of the effluent. Feeding of wastewater to the six pilot units was made through a perforated polyvinylchloride (PVC) rigid pipe with flow control.

The units were filled with water and after three weeks the wastewater was applied. The systems then operated for 17 months under different hydraulic conditions. During the first two months, no monitoring of the efficiency of the system was carried out, apart from measuring the $\mathrm{pH}$ of the inflow and outflow. After that, for 11 months (corresponding to days 60-391), the systems were monitored under a HLR of $3 \mathrm{~cm} \mathrm{~d}^{-1}$, with a nominal wetland detention time of 6.8 days. By the 8 th month (between days 214 and 242), the systems were not fed continuously due to the shutdown of the tannery production plant, although during that period the level of the liquid in the units was kept at approximately $5 \mathrm{~cm}$ below the surface by adding of stored tannery wastewater as required. A second period of operation occurred subsequently during 4 months (corresponding to days 392-511) under a HLR of $6 \mathrm{~cm} \mathrm{~d}^{-1}$, with a nominal wetland detention time of 3.4 days. Samples were periodically taken at the inlet and outlet of the CWs.

\section{Plant material}

The plant material used in the pilot units was chosen based on the plant species established in the surroundings of a wastewater discharge tank of the leather company: cattail (T. latifolia), yellow flag (I. pseudacorus), canna (C. indica) and St. Augustine grass ( $\mathrm{S}$. secundatum). These plants were transplanted from this site to the pilot units. The common reed (P. australis) was also used because it is very abundant in Portugal and it is frequently applied in CWs. It was transplanted from an industrial polluted site in Estarreja, Portugal (Oliveira et al., 2001). All the plants used for transplantation to the pilot units were apparently well established in their place of origin. The vegetation was planted by hand with a range of plants of $10 \mathrm{~m}^{-2}$. The plant material was placed in the substrate at a depth equal to the operational water level of the units. The number of plants was monitored throughout operation.

\section{Maintenance}

The systems were inspected on, at least, a weekly basis concerning the overall functioning. Major attention was given to the inlet flow, which was checked twice a week, as obstruction of the pipes due to suspended solids in the effluent could occur. A general cleaning of the pipes was usually undertaken twice a month.

\section{Data analysis}

Statistical analysis was performed using the SPSS program (SPSS Inc., Chicago, IL, USA; Version 12.0). The data was analyzed through one-way analysis of variance (ANOVA) to compare the performance of each bed concerning the removal of $\mathrm{BOD}_{5}, \mathrm{COD}$, TSS, TKN, $\mathrm{NH}_{3}, \mathrm{NO}_{3}^{-}$and Total P. To 
detect the statistical significance of differences $(p<0.05)$ between means of treatments, the Tukey test was performed.

\section{Results}

Tannery wastewater characterization

The characteristics of the tannery wastewater are presented in Table 1, demonstrating its variability during the year. The variations also occur through each working day. The variation of COD and $\mathrm{pH}$, determined hourly, was analyzed during two different days - the average COD and $\mathrm{pH}$ were $2010 \mathrm{mg} \mathrm{O}_{2} \mathrm{~L}^{-1}$ $( \pm 516)$ and $6.98( \pm 0.05)$, respectively, in one day, and $2068 \mathrm{mgO}_{2} \mathrm{~L}^{-1}( \pm 446)$ and $7.93( \pm 0.08)$, respectively, in another day.

Table 1 - Mean composition of the tannery wastewater for 1 year. Average, minimum and maximum values $( \pm \mathrm{SD})$ are shown

\begin{tabular}{lccc}
\hline & Average $\pm \mathrm{SD}$ & Minimum & Maximum \\
\hline $\mathrm{pH}^{\mathrm{a}}$ & $6.14 \pm 1.10$ & 4.62 & 8.13 \\
$\mathrm{COD}^{\mathrm{a}}\left(\mathrm{mg} \mathrm{O}_{2} \mathrm{~L}^{-1}\right)$ & $2250 \pm 565$ & 1100 & 3000 \\
$\mathrm{BOD}_{5}{ }^{\mathrm{a}}\left(\mathrm{mg} \mathrm{L}^{-1}\right)$ & $1000 \pm 88$ & 900 & 1200 \\
$\mathrm{TSS}^{\mathrm{b}}(\mathrm{mg} \mathrm{total}$ & & & \\
$\left.\mathrm{solids} \mathrm{L}^{-1}\right)$ & $92 \pm 36$ & 58 & 200 \\
$\mathrm{TKN}^{\mathrm{b}}\left(\mathrm{mg} \mathrm{TKN}^{-}\right.$ & & & \\
$\left.\mathrm{NL}^{-1}\right)$ & $188 \pm 17$ & 150 & 220 \\
$\mathrm{NH}_{3}{ }^{\mathrm{b}}\left(\mathrm{mg} \mathrm{NH}_{3}-\right.$ & & & \\
$\left.\mathrm{NL}^{-1}\right)$ & $100 \pm 14$ & 75 & 135 \\
$\mathrm{NO}_{3}^{-\mathrm{b}}\left(\mathrm{mg} \mathrm{NO}_{3}^{-}-\right.$ & & & \\
$\left.\mathrm{NL}^{-1}\right)$ & $44 \pm 9$ & 36 & 67 \\
$\mathrm{Total} \mathrm{P}^{\mathrm{b}}\left(\mathrm{mg} \mathrm{P} \mathrm{L}^{-1}\right)$ & $1.0 \pm 0.7$ & 0.1 & 2.0 \\
$\mathrm{Total} \mathrm{Cr}^{\mathrm{b}}$ & & & \\
$\left(\mathrm{mgCr} \mathrm{L}^{-1}\right)$ & $0.027 \pm 0.075$ & $<0.001$ & 0.360 \\
$\mathrm{Cr} \mathrm{VI}^{\mathrm{b}}\left(\mathrm{mg} \mathrm{Cr} \mathrm{L}^{-1}\right)$ & $0.004 \pm 0.006$ & $<0.001$ & 0.020 \\
\hline
\end{tabular}

a $n=44$.

b $n=24$.

\section{Development of plant material in the pilot units}

The growth of the plants was monitored during the operation of the pilot units. A limited natural colonization by some plants occurred in all units, except on the control unit, namely by Aster squamatus, Picris echioides, Polypogon viridis, Dactylis glomerata, Paspalum paspalodes, Vicia sativa, Sonchus oleraceus and Rumex crispus. No intervention was made to control their growth. The development of the plants in terms of total number of shoots is shown in Fig. 1. By the end of the first period (corresponding to day 391) of operation at an HLR of $3 \mathrm{~cm} \mathrm{~d}^{-1}$, the counting of the existing number of plants was 7 for Canna indica, 10 for T. latifolia, 200 for P. australis, 5 for I. pseudacorus, while $\mathrm{S}$. secundatum did not show any development. After the feed interruption period (between days 214 and 242), there was a $14 \%$ decrease for C. indica, a $17 \%$ decrease for I. pseudacorus, while there was an increase of $4 \%$ for T. latifolia and of $35 \%$ for P. australis. After the second period of operation, corresponding to four months (corresponding to days 392-511) at a higher HLR of $6 \mathrm{~cm} \mathrm{~d}^{-1}$, the counting of the existing number of plants was 3 for $C$. indica, 25 for T. latifolia, 400 for P. australis and 9 for I. pseudacorus. S. secundatum almost disappeared.

\section{Removal eficiency of the pilot units}

The efficiency of the pilot units subject to the different hydraulic conditions was monitored through their operation, and the characteristics of the wastewater collected from the inflow and outflow of each pilot unit are shown in Tables 2 and 3.

In the first 2 months of wastewater application, the outflow $\mathrm{pH}$ of the units was more alkaline than in the following periods of operation, varying between 8.69 and 10.39 (data not shown). A decrease of the $\mathrm{pH}$ at the outflow of all pilot units occurred with time, but the $\mathrm{pH}$ was higher at the outflow than that observed at the inflow at all times. When operating at an HLR of $3 \mathrm{~cm} \mathrm{~d}^{-1}$, the average $\mathrm{pH}$ at the inflow was 7.45 , while the $\mathrm{pH}$ at the outflow, for the different units, varied between 7.95 and 9.88. When operating at an HLR of $6 \mathrm{~cm} \mathrm{~d}^{-1}$ the

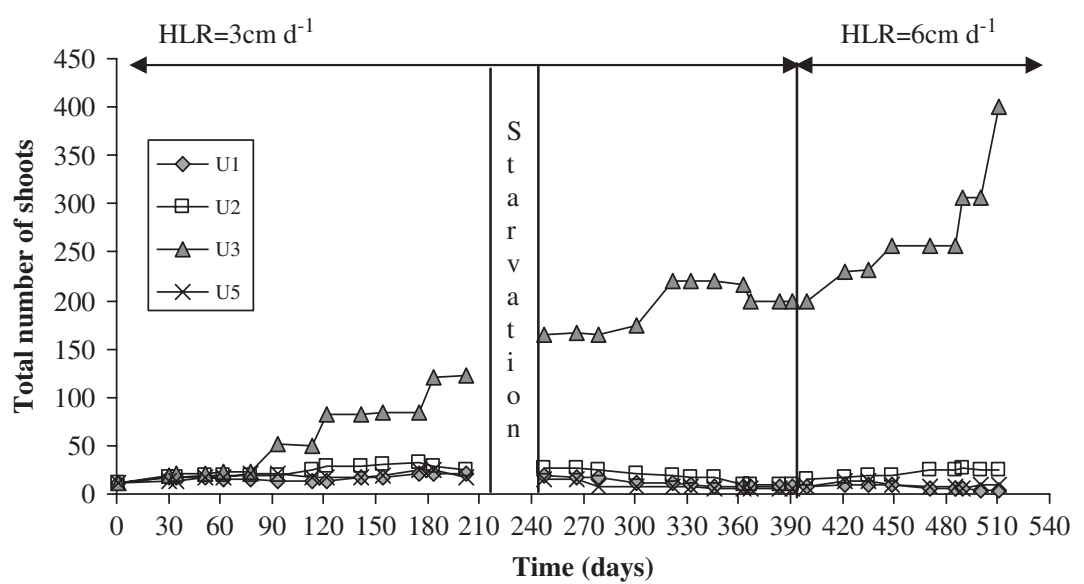

Fig. 1 - Variation in number of shoots in the pilot units during the systems operation. Unit 1: Canna indica, Unit 2: Typha latifolia, Unit 3: Phragmites australis and Unit 5: Iris pseudacorus. No loading occurred between days 214 and 242. 


\begin{tabular}{|c|c|c|c|c|c|c|c|}
\hline \multirow[t]{2}{*}{ Parameters } & \multicolumn{7}{|c|}{ Average results (min.-max.) } \\
\hline & Inflow & $\mathrm{U} 1^{\mathrm{a}}$ & $\mathrm{U}^{\mathrm{a}}$ & $\mathrm{U}^{\mathrm{a}}$ & $\mathrm{U} 4^{\mathrm{a}}$ & $\mathrm{U}^{\mathrm{a}}$ & $\mathrm{U}^{\mathrm{a}}$ \\
\hline $\mathrm{pH}^{\mathrm{b}}$ & $7.45(4.64-8.75)$ & $\begin{array}{c}8.64 \\
(7.95-9.42)\end{array}$ & $8.61(8.01-9.34)$ & $8.69(8.06-9.62)$ & $9.03(8.09-9.85)$ & $\begin{array}{c}9.15 \\
(8.42-9.88)\end{array}$ & $8.77(8.04-9.72)$ \\
\hline $\mathrm{COD}^{\mathrm{b}}\left(\mathrm{mgO}_{2} \mathrm{~L}^{-1}\right)$ & $\begin{array}{c}1966 \\
(1108-3141)\end{array}$ & $\begin{array}{c}882 \\
(500-1400)\end{array}$ & $855(550-1400)$ & $833(550-1290)$ & $892(554-1300)$ & $\begin{array}{c}884 \\
(600-1325)\end{array}$ & $913(600-1312)$ \\
\hline $\mathrm{BOD}_{5}{ }^{\mathrm{c}}\left(\mathrm{mgL}^{-1}\right)$ & $875(727-1080)$ & $\begin{array}{c}438 \\
(350-525)\end{array}$ & $444(350-550)$ & $449(400-530)$ & $468(380-570)$ & $469(400-560)$ & $476(400-600)$ \\
\hline $\begin{array}{l}\text { TSS }^{\mathrm{d}} \text { (mg total } \\
\left.\text { solids } \mathrm{L}^{-1}\right)\end{array}$ & $75(33-125)$ & $19(7-43)$ & $18(4-33)$ & $19(5-38)$ & $21(7-39)$ & $20(7-40)$ & $20(7-40)$ \\
\hline $\begin{array}{l}\mathrm{TKN}^{\mathrm{c}}(\mathrm{mg} \mathrm{TKN}- \\
\left.\mathrm{NL}^{-1}\right)\end{array}$ & $143(90-230)$ & $\begin{array}{c}106 \\
(62-170)\end{array}$ & $107(65-180)$ & $105(62-176)$ & $104(57-173)$ & $104(56-165)$ & $106(67-168)$ \\
\hline $\begin{array}{l}\mathrm{NH}_{3}{ }^{\mathrm{c}}\left(\mathrm{mgNH}_{3}-\right. \\
\left.\mathrm{NL}^{-1}\right)\end{array}$ & $74(45-100)$ & $59(33-86)$ & $59(35-82)$ & $61(34-88)$ & $61(37-84)$ & $60(37-81)$ & $59(37-83)$ \\
\hline $\begin{array}{l}\mathrm{NO}_{3}^{-\mathrm{c}}\left(\mathrm{mgNO}_{3}^{-}-\right. \\
\left.\mathrm{NL}^{-1}\right)\end{array}$ & $36(20-60)$ & $31(18-50)$ & $31(18-51)$ & $31(18-52)$ & $31(17-48)$ & $31(18-52)$ & $32(18-52)$ \\
\hline Total $\mathrm{P}^{\mathrm{e}}\left(\mathrm{mg} \mathrm{P} \mathrm{L}^{-1}\right)$ & $0.30(0.08-0.45)$ & $\begin{array}{c}0.42 \\
(0.12-0.93)\end{array}$ & $0.37(0.09-1.41)$ & $0.44(0.1-1.47)$ & $0.46(0.13-1.36)$ & $\begin{array}{c}0.56 \\
(0.09-1.63)\end{array}$ & $0.40(0.09-0.98)$ \\
\hline $\begin{array}{l}\text { Total } \mathrm{Cr}^{\mathrm{d}} \\
\left(\mathrm{mgCr} \mathrm{L}^{-1}\right)\end{array}$ & $\begin{array}{c}0.017 \\
(<0.001-0.025)\end{array}$ & $<0.001$ & $\begin{array}{c}0.004 \\
(<0.001-0.005)\end{array}$ & $\begin{array}{c}0.012 \\
(<0.001-0.025)\end{array}$ & $\begin{array}{c}0.008 \\
(<0.001-0.015)\end{array}$ & $\begin{array}{c}0.005 \\
(0.001-0.012)\end{array}$ & $\begin{array}{c}0.006 \\
(<0.001-0.012)\end{array}$ \\
\hline $\mathrm{Cr} \mathrm{VI}^{\mathrm{d}}\left(\mathrm{mgCr} \mathrm{L}^{-1}\right)$ & $<0.001$ & $<0.001$ & $<0.001$ & $<0.001$ & $<0.001$ & $<0.001$ & $<0.001$ \\
\hline $\begin{array}{l}\text { a Units: U1: Canna } \\
\text { b } n=27 . \\
\text { c } n=10 . \\
\text { d } n=19 . \\
\text { e } n=13 .\end{array}$ & a, U2: Typha lc & & & enotaphrum s & atum, U5: Iris & dacorus, U6: & \\
\hline
\end{tabular}

\section{Table 3 - Mean composition of the inflow and outflow of the pilot units for a HLR of $6 \mathrm{~cm} \mathrm{~d}^{-1}$. Minimum and maximum} values are indicated in brackets

\begin{tabular}{|c|c|c|c|c|c|c|c|}
\hline \multirow[t]{2}{*}{ Parameters } & \multicolumn{7}{|c|}{ Average results (min.-max.) } \\
\hline & Inflow & $\mathrm{U} 1^{\mathrm{a}}$ & $\mathrm{U} 2^{\mathrm{a}}$ & $\mathrm{U}^{\mathrm{a}}$ & $\mathrm{U} 4^{\mathrm{a}}$ & $\mathrm{U}^{\mathrm{a}}$ & $\mathrm{U}^{\mathrm{a}}$ \\
\hline $\mathrm{pH}^{\mathrm{b}}$ & $\begin{array}{c}6.55 \\
(5.84-7.13)\end{array}$ & $\begin{array}{c}8.18 \\
(8.03-8.54)\end{array}$ & $\begin{array}{c}8.25 \\
(8.13-8.48)\end{array}$ & $\begin{array}{c}8.15 \\
(8.06-8.37)\end{array}$ & $\begin{array}{c}8.33 \\
(8.15-8.64)\end{array}$ & $\begin{array}{c}8.52 \\
(8.33-8.78)\end{array}$ & $\begin{array}{c}8.17 \\
(8.01-8.38)\end{array}$ \\
\hline $\mathrm{COD}^{\mathrm{b}}\left(\mathrm{mgO}_{2} \mathrm{~L}^{-1}\right)$ & $\begin{array}{c}2093 \\
(1755-2669)\end{array}$ & $805(684-900)$ & $745(600-870)$ & $776(672-880)$ & $810(900-700)$ & $\begin{array}{c}778 \\
(672-870)\end{array}$ & $821(740-915)$ \\
\hline $\mathrm{BOD}_{5}{ }^{\mathrm{b}}\left(\mathrm{mgL}^{-1}\right)$ & $898(740-1300)$ & $436(350-540)$ & $436(345-630)$ & $449(350-600)$ & $449(370-590)$ & $\begin{array}{c}465 \\
(370-620)\end{array}$ & $453(350-600)$ \\
\hline $\begin{array}{l}\text { TSS }^{\mathrm{b}} \text { (mg total } \\
\text { solids } \mathrm{L}^{-1} \text { ) }\end{array}$ & $79(66-100)$ & $24(20-33)$ & $23(19-31)$ & $24(19-30)$ & $25(18-32)$ & $25(19-33)$ & $24(19-32)$ \\
\hline $\begin{array}{l}\mathrm{TKN}^{\mathrm{c}}(\mathrm{mg} \mathrm{TKN}- \\
\left.\mathrm{NL}^{-1}\right)\end{array}$ & $126(90-162)$ & $94(74-120)$ & $96(74-125)$ & 97 (70-119) & $96(65-122)$ & 94 (63-119) & 95 (68-119) \\
\hline $\begin{array}{l}\mathrm{NH}_{3}{ }^{\mathrm{c}}\left(\mathrm{mgNH}_{3}-\right. \\
\left.\mathrm{NL}^{-1}\right)\end{array}$ & $88(75-100)$ & $79(70-87)$ & $82(73-94)$ & $80(72-90)$ & $79(70-88)$ & $81(73-88)$ & $81(72-93)$ \\
\hline $\begin{array}{l}\mathrm{NO}_{3}^{-\mathrm{c}}\left(\mathrm{mgNO}_{3}^{-}-\right. \\
\left.\mathrm{NL}^{-1}\right)\end{array}$ & $30(20-40)$ & $28(18-36)$ & $27(19-36)$ & $28(17-39)$ & $27(19-35)$ & $27(18-36)$ & $28(18-37)$ \\
\hline Total $\mathrm{P}^{\mathrm{b}}\left(\mathrm{mg} \mathrm{PL}^{-1}\right)$ & $\begin{array}{c}0.25 \\
(0.20-0.38)\end{array}$ & $\begin{array}{c}0.26 \\
(0.20-0.39)\end{array}$ & $\begin{array}{c}0.28 \\
(0.21-0.38)\end{array}$ & $\begin{array}{c}0.29 \\
(0.21-0.38)\end{array}$ & $\begin{array}{c}0.27 \\
(0.21-0.39)\end{array}$ & $\begin{array}{c}0.28 \\
(0.21-0.4)\end{array}$ & $\begin{array}{c}0.27 \\
(0.21-0.39)\end{array}$ \\
\hline $\begin{array}{l}\text { Total } \mathrm{Cr}^{\mathrm{b}} \\
\left(\mathrm{mgCr} \mathrm{L}^{-1}\right)\end{array}$ & $\begin{array}{c}0.010 \\
(<0.001-0.027)\end{array}$ & $\begin{array}{c}0.008 \\
(<0.001-0.027)\end{array}$ & $\begin{array}{c}0.022 \\
(<0.001-0.080)\end{array}$ & $\begin{array}{c}0.010 \\
(<0.001-0.031)\end{array}$ & $\begin{array}{c}0.012 \\
(<0.001-0.026)\end{array}$ & $\begin{array}{c}0.025 \\
(0.001-0.049)\end{array}$ & $\begin{array}{c}0.018 \\
(<0.001-0.040)\end{array}$ \\
\hline $\mathrm{Cr} \mathrm{VI}{ }^{\mathrm{b}}\left(\mathrm{mgCr} \mathrm{L}^{-1}\right)$ & $\begin{array}{c}0.005 \\
(<0.001-0.010)\end{array}$ & $<0.001$ & $<0.001$ & $<0.001$ & $<0.001$ & $<0.001$ & $<0.001$ \\
\hline $\begin{array}{l}\text { a Units: U1: Canna } \\
\text { b } n=12 . \\
\text { с } n=6 .\end{array}$ & ica, U2: Typha l & folia, U3: Phragm & es australis, U4: & notaphrum sec & tum, U5: Iris $p$ & corus, U6: & \\
\hline
\end{tabular}


average $\mathrm{pH}$ of the inflow was 6.55, while the outflow values varied between 8.01 and 8.78 . The performance of the units concerning organic matter and nutrients removal was measured thereafter.

In terms of organic matter removal (COD and $\mathrm{BOD}_{5}$ ) no significant differences were found between the different pilot units. For an HLR of 3 and $6 \mathrm{~cm} \mathrm{~d}^{-1}$ the average COD inflow concentration was 1966 and $2093 \mathrm{mgO}_{2} \mathrm{~L}^{-1}$, respectively. The removal efficiencies of the pilot units varied from $41 \%$ to $67 \%$ for an HLR of $3 \mathrm{~cm} \mathrm{~d}^{-1}$, and from $54 \%$ to $73 \%$ for an HLR of $6 \mathrm{~cm} \mathrm{~d}^{-1}$. The average $\mathrm{BOD}_{5}$ inflow concentration was 875 and $898 \mathrm{mgL}^{-1}$ for an HLR of 3 and $6 \mathrm{~cm} \mathrm{~d}^{-1}$, respectively. At the outflow of the pilot units the removal efficiency varied between 41 and 55\% for an HLR of $3 \mathrm{~cm} \mathrm{~d}^{-1}$, and between $41 \%$ and $58 \%$ for an HLR of $6 \mathrm{~cm} \mathrm{~d}^{-1}$

The TSS inflow concentration ranged between 33 and $125 \mathrm{mg}$ total solids $\mathrm{L}^{-1}$ and the removal efficiencies varied between $48 \%$ and $92 \%$ for $3 \mathrm{~cm} \mathrm{~d}^{-1}$ and between $62 \%$ and $77 \%$ for $6 \mathrm{~cm} \mathrm{~d}^{-1}$. There were no significant differences between the units for the two HLRs.

Nutrients removal was in general low for the two hydraulic conditions. The TKN and $\mathrm{NH}_{3}$ inflow concentrations ranged between $90-230 \mathrm{mg}$ TKN-N L ${ }^{-1}$ and $45-100 \mathrm{mg} \mathrm{NH}_{3}-\mathrm{NL}^{-1}$. For the HLR of $3 \mathrm{~cm} \mathrm{~d}^{-1}$, the removal efficiencies varied from $18 \%$ to $42 \%$ for TKN and $11-27 \%$ for $\mathrm{NH}_{3}$. For an HLR of $6 \mathrm{~cm} \mathrm{~d}^{-1}$ the average removal efficiencies for TKN and $\mathrm{NH}_{3}$ were in the range of $16-30 \%$ and $2-16 \%$, respectively. There were no significant differences between the units for the two HLRs. The $\mathrm{NO}_{3}^{-}$inflow concentration ranged between 20 and $60 \mathrm{mg} \mathrm{NO}_{3}^{-}-\mathrm{NL}^{-1}$; at the outlet concentration varied between 17 and $52 \mathrm{mgNO}_{3}^{-}-\mathrm{NL}^{-1}$.

Phosphorus and chromium (total and hexavalent) were only detected at low concentrations at the inflow and outflow of the units. For phosphorous removal, there were no significant statistical differences between the pilot units. The chromium concentration at the outflow of the units was below the detection limit, being the average inflow concentration of $0.010 \mathrm{mgCr} \mathrm{L}^{-1}$. These low levels are due to the fact that the leather production plant does not use chromium in high amounts.
Fig. 2 shows, as an example, the pattern of COD removal during the system operation at the two HLRs for the P. australis unit. The outflow values of COD, for all units, gradually decreased at the beginning of operation but remained fairly constant thereafter. The efficiency of COD removal was not affected by the feed interruption period, corresponding to the tannery plant shutdown at day 214. When the feed was restarted, after one month, the efficiency was resumed. The COD removal efficiency was not significantly affected by the time of the year, varying between $41 \%$ and $67 \%$ in Spring/Summer (April-September) and between $41 \%$ and $65 \%$ in Autumn/Winter (October-March).

\section{Relationship between removal efciency and organic load}

The removal of COD, $\mathrm{BOD}_{5}$ and TSS was proportional to the influent load. The linear relationship between mass removal and mass loading is illustrated in Figs. 3-5. For an HLR of $3 \mathrm{~cm} \mathrm{~d}^{-1}$, the organic loading (COD) inflow of the units varied between 332 and $942 \mathrm{kgha}^{-1} \mathrm{~d}^{-1}$, being the mass removal between 152 and $582 \mathrm{~kg} \mathrm{ha}^{-1} \mathrm{~d}^{-1}$. For an HLR of $6 \mathrm{~cm} \mathrm{~d}^{-1}$, the organic loading (COD) varied between 1053 and $1602 \mathrm{kgha}^{-1} \mathrm{~d}^{-1}$, being the mass removal between 573 and $1092 \mathrm{~kg} \mathrm{ha}^{-1} \mathrm{~d}^{-1}$. In terms of $\mathrm{BOD}_{5}$, the organic loading varied from 218 to $324 \mathrm{~kg} \mathrm{ha}^{-1} \mathrm{~d}^{-1}$, for a $3 \mathrm{~cm} \mathrm{~d}^{-1}$, being the mass removal between 92 and $168 \mathrm{~kg} \mathrm{ha}^{-1} \mathrm{~d}^{-1}$, while for an HLR of $6 \mathrm{~cm} \mathrm{~d}^{-1}$ it varied between 444 and $780 \mathrm{~kg} \mathrm{ha}^{-1} \mathrm{~d}^{-1}$, and the mass removal was between 198 and $456 \mathrm{kgha}^{-1} \mathrm{~d}^{-1}$. The maximum and minimum TSS loading was, respectively, 10 and $38 \mathrm{kgha}^{-1} \mathrm{~d}^{-1}$ for $3 \mathrm{~cm} \mathrm{~d}^{-1}$ and 40 and $60 \mathrm{kgha}^{-1} \mathrm{~d}^{-1}$ for $6 \mathrm{~cm} \mathrm{~d}^{-1}$, being the correspondent mass removals variations of 6-33 and $25-45 \mathrm{kgha}^{-1} \mathrm{~d}^{-1}$.

\section{Discussion}

In this study, six constructed wetland pilot unit systems receiving tannery wastewater operated for 17 months using horizontal subsurface flow under two different HLRs, 3 and

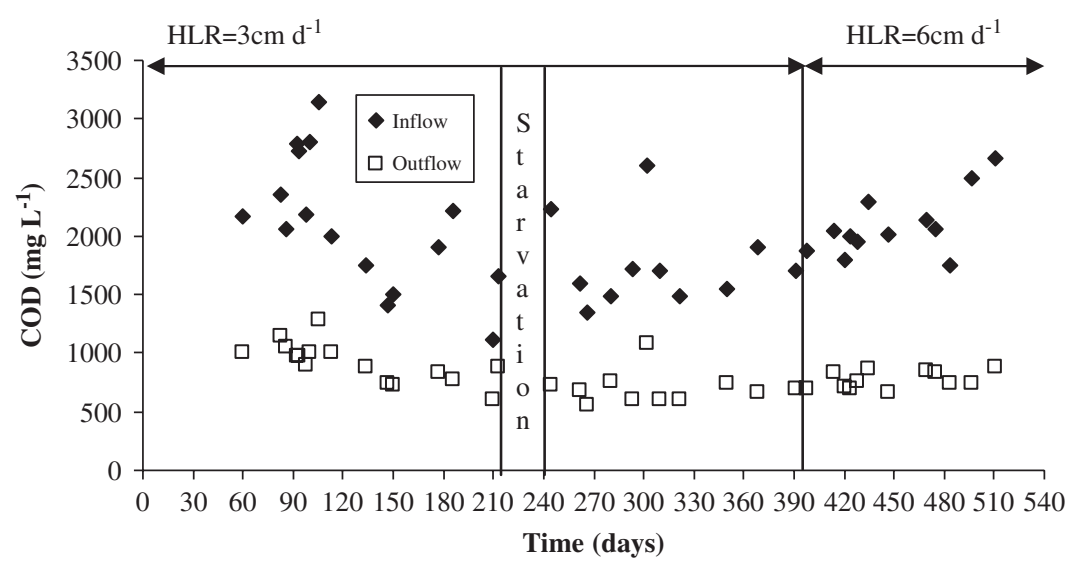

Fig. 2 - COD at the inflow and outflow of the Phragmites australis pilot unit during the time of operation, for the two HLRs applied. No loading occurred between days 214 and 242. 


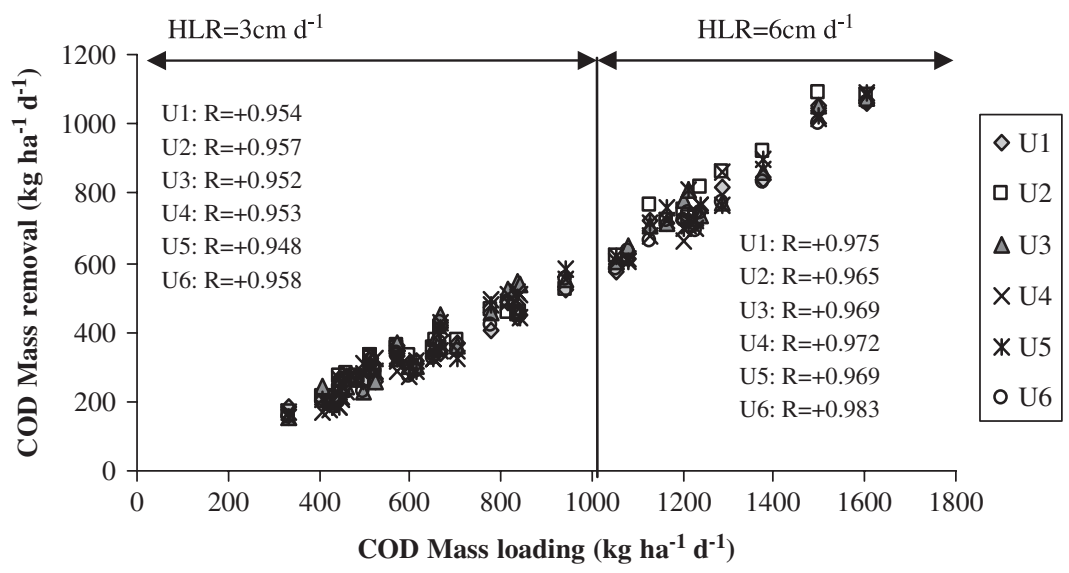

Fig. 3 - COD loading vs. COD removal. Unit 1: Canna indica, Unit 2: Typha latifolia, Unit 3: Phragmites australis, Unit 4: Stenotaphrum secundatum, Unit 5: Iris pseudacorus and Unit 6: control. The coefficients of the linear correlation are represented all with $p<0.05$.

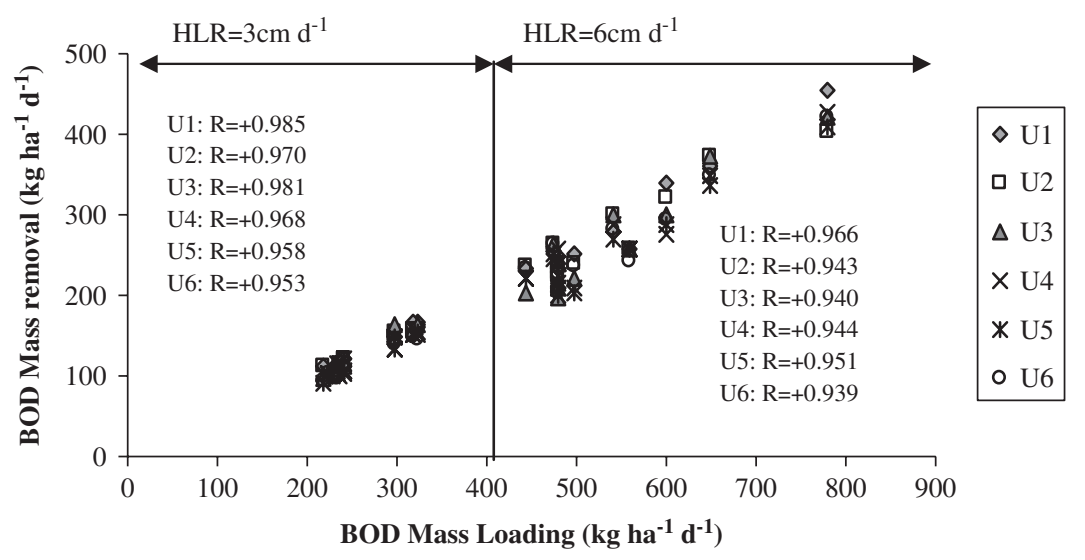

Fig. 4 - BOD $_{5}$ loading vs. BOD $_{5}$ removal. Unit 1: Canna indica, Unit 2: Typha latifolia, Unit 3: Phragmites australis, Unit 4: Stenotaphrum secundatum, Unit 5: Iris pseudacorus and Unit 6: control. The coefficients of the linear correlation are represented all with $\boldsymbol{p}<0.05$.

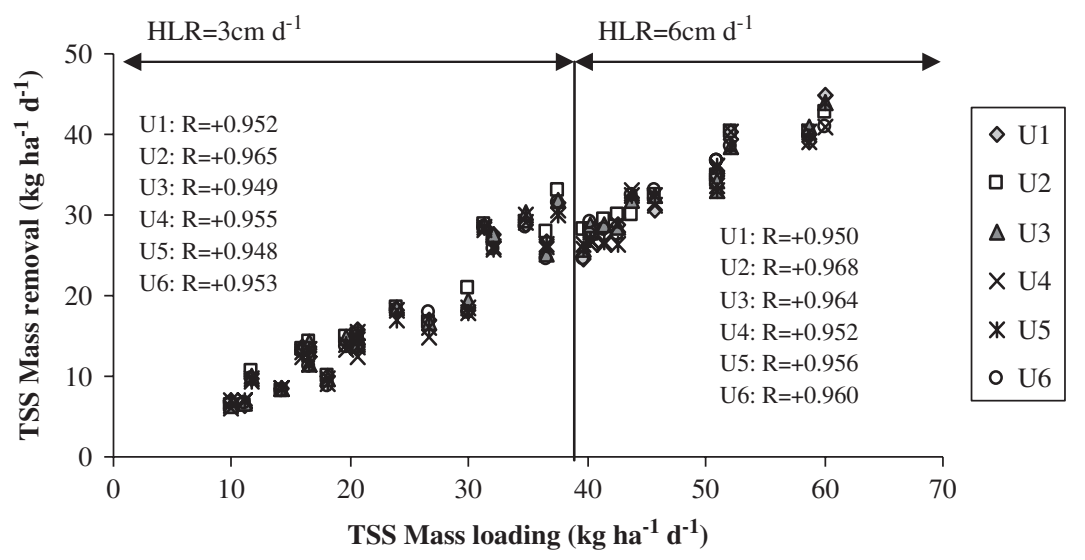

Fig. 5 - TSS loading vs. TSS removal. Unit 1: Canna indica, Unit 2: Typha latifolia, Unit 3: Phragmites australis, Unit 4: Stenotaphrum secundatum, Unit 5: Iris pseudacorus and Unit 6: control. The coefficients of the linear correlation are represented all with $\boldsymbol{p}<\mathbf{0 . 0 5}$. 
$6 \mathrm{~cm} \mathrm{~d}^{-1}$. In the leather manufacturing, different operations and processes result in effluents with different compositions (Song et al., 2000), and wastewater treatment systems should withstand such variability. The type of wastewater may influence crucially the survival of plants in a CW. In the present study, the patterns of the tannery wastewater produced were characterized. Prior to the operation of the pilot units, the one year assessment of the chemical characteristic of the wastewater has revealed that the composition was variable, with the COD ranging from 1100 to $3000 \mathrm{mg} \mathrm{O}_{2} \mathrm{~L}^{-1}$ and the $\mathrm{BOD}_{5}$ from 900 to $1200 \mathrm{mgL}^{-1}$. The inflow to the pilot units varied thereafter in a similar manner.

The choice of different plant species should take into account some factors such as the rooting depth, plant productivity and tolerance to high loads of wastewater (Brix, 1994). The main emergent macrophyte species used in CWs in the Mediterranean countries are Canna spp., Iris spp., Cyperus spp., Typha spp., Phragmites spp., Juncus spp., Poaceae spp. and Paspalum spp. (Korkusuz, 2005). In this study, plant distribution and propagation varied according to the species planted in the pilot units. P. australis, which is considered as highly invasive, and T. latifolia were the species that were better established in the units, while the propagation and development of Iris spp. and Canna spp. was reduced. The former plants supported different hydraulic conditions. The potential of using P. australis and T. latifolia in CWs is found in literature in several studies dealing with domestic and industrial-tannery, dye-rich wastewater, food processing and high-strength winery-wastewater treatment (Vymazal, 2005; Vymazal and Krőpfelová, 2005; Mbuligwe, 2005; Kucuk et al., 2003; Shepherd et al., 2001; Vrhovšek et al., 1996). Vymazal (2005) also reported the successful use of Iris spp. (pseudacorus and sibrica) in CWs for urban wastewater treatment. In a similar manner to Iris spp. and Canna spp., the S. secundatum used in the present study was also clearly not suitable for tannery wastewater treatment as it was not able to survive. Less frequently used plants have also been tested in CWs for wastewater treatment. Klomjek and Nitisoravut (2005) evaluated the feasibility of using CWs to remove pollutants from saline wastewater using eight emergent plants. They reported that among Typha angustifolia, Digitaria bicornis, Cyperus corymbosus, Brachiaria mutica, Vetiveria zizaniodes, Spartina patents, Leptochloa fusca and Echinodorus cordifolius, the first two, T. angustifolia and D. bicornis, were clearly superior for nitrogen uptake and $\mathrm{BOD}_{5}$ removal. Maine et al. (2006), in a free water surface CW, tested several locally available macrophytes (Eichhornia crassipes, Typha domingensis and Pontederia cordata) in order to treat wastewater from a metallurgic industry, aiming at nutrient and metal removal. The E. crassipes became dominant and covered about $80 \%$ of the water surface, and T. domingensis and Panicum elephantipes developed as accompanying species, with $14 \%$ and $4 \%$ cover, respectively. The tannery wastewater applied to the CWs, in the present study, may have a negative effect upon the growth of wetland species due to the complexity of its composition. There are several possible causes for the inhibition of plant growth, such as the presence of toxic levels of contaminants and deficiency of nutrients for plant development. The $\mathrm{pH}$ of the substrate may have also influenced plant growth. In the first weeks of application of the wastewater to the plant units, the inflow was slightly alkaline and the outflow wastewater was strongly alkaline, as the $\mathrm{pH}$ of the substrate was strongly alkaline (9.75). With time, the outflow $\mathrm{pH}$ stabilized to moderately alkaline. The optimum $\mathrm{pH}$ for plant development is considered to be between 3.0 and 8.5 for T. latifolia, 3.7 to 8.0 for P. australis, 6.0 to 7.5 for I. pseudacorus (USEPA, 2000a), 5.5 to 7.5 for C. indica (Jett, 2005) and 6.0 to 8.5 for S. secundatum (Smith and Valenzuela, 2002). It is possible that the plants could have had some difficulty in developing and propagating considering that the $\mathrm{pH}$ of the matrix, particularly at the beginning of operation, was out of their optimum range.

CWs with subsurface horizontal flow usually provide high removal of organic matter $\left(\mathrm{BOD}_{5}\right.$ and $\left.\mathrm{COD}\right)$ and suspended solids but lower nutrient removal (Vymazal, 2005; Kadlec et al., 2000). In this study, for the HLR of $3 \mathrm{~cm} \mathrm{~d}^{-1}$, the maximum removal efficiency in terms of COD was $67 \%$ for an average inflow of $1966 \mathrm{mg} \mathrm{O}_{2} \mathrm{~L}^{-1}\left(590 \mathrm{kgha}^{-1} \mathrm{~d}^{-1}\right), 55 \%$ for $\mathrm{BOD}_{5}$ for an average inflow of $875 \mathrm{mgL}^{-1}\left(263 \mathrm{kgha}^{-1} \mathrm{~d}^{-1}\right)$ and $92 \%$ for TSS for an average inflow of $75 \mathrm{mgL}^{-1}\left(23 \mathrm{~kg} \mathrm{ha}^{-1} \mathrm{~d}^{-1}\right)$. Concerning the HLR of $6 \mathrm{~cm} \mathrm{~d}^{-1}$, the maximum removal efficiency in terms of COD was $73 \%$ for an average inflow of $2093 \mathrm{mgO}_{2} \mathrm{~L}^{-1}\left(1256 \mathrm{kgha}^{-1} \mathrm{~d}^{-1}\right)$, for $\mathrm{BOD}_{5}$ was $58 \%$ for an average inflow of $898 \mathrm{mgL}^{-1}\left(539 \mathrm{kgha}^{-1} \mathrm{~d}^{-1}\right)$ and for TSS was $77 \%$ for an average inflow of $79 \mathrm{mgL}^{-1}\left(47 \mathrm{kgha}^{-1} \mathrm{~d}^{-1}\right)$. The COD at the outlet of the CWs was in average 850 $( \pm 191) \mathrm{mgO}_{2} \mathrm{~L}^{-1}$ despite the different HLRs applied, which may indicate that a part of the COD from the tannery wastewater is not readily biodegradable in the system under the different hydraulic retention times tested. Daniels (2001a) reported that in the first year of operation of a five-day retention time pilot root-zone treatment with reeds, $80-85 \%$ of the COD of a tannery effluent was removed, for an inlet COD level ranging from 1000 to $2000 \mathrm{mgL}^{-1}$. In another study reported by the same author, carried out with effluent of the manufacture of finished shoe upper leather from multisource wet blue with a typical COD inflow of $1160 \mathrm{mgL}^{-1}$, reductions of $85 \%, 82 \%$ and $70 \%$ COD were obtained, for CWs planted with two subspecies of Glyceria maxima and Phragmites, respectively, in a five day root-zone system. Both species proved to be extremely robust and survived shock dosing, long periods of drying out, total immersion and cold (Daniels, 1998). However, no detailed information is provided on the hydraulic loadings applied to the systems. In contrast with these high removal efficiencies, Kucuk et al. (2003) reported a maximum COD removal of $30 \%$ for a tannery wastewater with an inlet concentration of $300 \mathrm{mg} \mathrm{L}^{-1}$, using a hydraulic retention time of 8 days. It is thus clear that the specificity of the different tannery wastewaters affect their biodegradability in a CW.

Nutrients removal occurred to lower extents, but was found to be within the range reported by other authors for subsurface horizontal flow CWs (Mantovi et al., 2003; García et al., 2005), although for different types of wastewater. Wetland plants are known to take up nutrients but this amount may be insignificant compared to the wastewater inflow loading (Brix, 1994, 1997). According to Vymazal (2005) the removal of nutrients (nitrogen and phosphorus) is usually low in CWs and does not exceed $50 \%$ when dealing with municipal sewage. Also, according to Tanner (2001), on an annual basis, the net accumulation of nutrients in plant tissues in mature wetlands is reduced. However, factors such as climate, 
nutrient regime and type of plant can play a significant role in this mechanism (Vymazal, 2005; Tanner, 2001). The phosphorus uptake capacity of macrophytes is reported to be lower than the nitrogen uptake capacity (Brix, 1994). In the present study, due to the low inflow levels of phosphorus, we cannot infer about the capacity of the different plants to remove it from the wastewater. The removal of chromium was also negligible in the present study, but it is possible that differences in chromium removal would have been achieved between the units if the concentration of the metal in the effluent was higher, as different plants have different capacities to remove heavy metals (Maine et al., 2006; Kadlec et al., 2000).

In the present study the ability of treating wastewater at high organic loading-typical of tannery wastewater-was evaluated. The organic loading removal achieved in the pilot units was high, up to $1092 \mathrm{kgCOD} \mathrm{ha}^{-1} \mathrm{~d}^{-1}, 456 \mathrm{kgBOD}_{5} \mathrm{ha}^{-1} \mathrm{~d}^{-1}$ and $45 \mathrm{kgTSS} \mathrm{ha}^{-1} \mathrm{~d}^{-1}$, increasing with the influent load in a linear correlation. This behavior corresponds to a first-order kinetics, showing that the removal rate was proportional to the inflow amount. In Tanner (2001) monotonic relationships between $\mathrm{BOD}$ and $\mathrm{COD}$ mass loading and removal rates are also presented, with little difference between planted and unplanted beds. Shepherd et al. (2001) used a CW for winery wastewater treatment with similar average organic loadings, varying between 345 and $1640 \mathrm{kgCODha}^{-1} \mathrm{~d}^{-1}$, and reported removal efficiencies of ca. $99 \%$, while in the present study a maximum removal efficiency of $73 \%$ was achieved. For horizontal subsurface beds, some authors do not recommend the application of organic loadings higher than $67 \mathrm{kgBOD}_{5} \mathrm{ha}^{-1} \mathrm{~d}^{-1}$ (Metcalf and Eddy Inc., 1991) or out of the range of $67-157 \mathrm{kgBODha}^{-1} \mathrm{~d}^{-1}$, and for TSS 45-168 kg TSS ha ${ }^{-1} \mathrm{~d}^{-1}$ (USEPA, 2000b). García et al. (2004) have reported that in order to obtain a $\mathrm{BOD}_{5}$ removal of $90 \%$, for urban wastewater, an organic surface loading of $200 \mathrm{kgha}^{-1} \mathrm{~d}^{-1}$ should not be exceeded (based on the first year of operation system). For the treatment of tannery wastewater, there is a need for appropriate design parameters.

No significant differences were found between the planted and unplanted systems during the 17 months of operation of the systems. Plants can contribute to wastewater treatment processes in a number of ways, such as settlement of suspended solids, providing surface area for microorganisms, increasing uptake of nutrients and trace elements and providing oxygen release (Kadlec et al., 2000; USEPA, 2000a; Brix, 1994, 1997). The beneficial role of plants in CWs is not always evident, and that seems to depend on several parameters, such as the time length of operation, type of vegetation and characteristics of the wastewater. Huang et al. (2000) found no difference in the removal of ammonium and TKN from domestic wastewater as a result of the presence of plants in a CW. Baptista et al. (2003) also reported similar performances in a CW planted with Phragmites and in unplanted units, when treating filtered beer with an average $\mathrm{BOD}_{5}$ concentration of $104 \mathrm{mgL}^{-1}$ (91\% and 92\% removal, respectively). The similar performance of the planted and unplanted beds obtained in the present study may be explained by the fact that the units had not reached maturity. A complete root-rhizome development for a newly CW may require 3-5 years (Kadlec et al., 2000). For Phragmites, three to four growing seasons are usually needed to reach maximum standing crop but in some systems it may take even longer (Vymazal and Krőpfelová, 2005). Vrhovšek et al. (1996) studied the application of CWs with Carex gracillis and P. australis to the secondary treatment of wastewaters from a food processing plant, showing that depuration improved with bed maturity, and after several years a continuous efficiency of more than $90 \%$ was obtained regarding the removal of $\mathrm{BOD}_{5}$, COD and orthophosphate. Other studies show improvements in performance in planted beds. Mbuligwe (2005) reported for the treatment of a dye-rich wastewater, with an organic loading of $106 \mathrm{kgCODha}^{-1} \mathrm{~d}^{-1}$, cattail and coco yam units outperformed an unplanted unit in terms of organic removal efficiency by $17.5-21.7 \%$, being the organic removals of 86.8 , 92.1 and $64.4 \mathrm{~kg} \mathrm{COD} \mathrm{ha}^{-1} \mathrm{~d}^{-1}$, respectively. However, there are authors who suggest that the primary benefits of vegetation in these systems may be mainly insulation and esthetics (Mæhlum and Stålnacke, 1999).

The findings from this study show that the application of CWs systems to the treatment of tannery effluents may be an attractive approach for integrated secondary treatment, but longer term operation of such units is important to ascertain for the role and benefits of the plants in such systems.

\section{Conclusions}

The aim of this study was to investigate the application of different plant species in CWs receiving wastewater from a tannery production plant. The conclusions are as follows:

1. The plants T. latifolia and P. australis were the plant species better adapted to tannery wastewater in terms of survival and propagation.

2. CWs with horizontal subsurface flow seem to be a viable alternative for reducing the organic matter content from tannery wastewater, being able to tolerate inflow fluctuations, including interruptions in the feed.

3. Nutrient removal is low when compared with the removal efficiencies achieved for $\mathrm{COD}$ and $\mathrm{BOD}_{5}$.

4. The fact that the plant beds may have not reached maturity may contribute to the similar performance obtained for vegetated and unvegetated units.

\section{Acknowledgments}

The authors thank Dias Ruivo, Curtumes e Produtos Industriais, Lda for making possible the establishment of this project. Cristina S.C. Calheiros wishes to thank a research grant from Fundação para a Ciência e Tecnologia (FCT), Portugal (SFRH/BDE/15507/2004). The work was supported by the Project POCI/AMB/60126/2004 financed by Medida V.4-Acç ão V.4.1 of the Programa Operacional Ciência e Inovação 2010 (Fundação para a Ciência e Tecnologia). The authors thank maxit-Argilas Expandidas, SA that kindly offered Filtralite ${ }^{\circledR}$. We thank Dr. Paulo Alves from Departamento de Botânica, Faculdade de Ciências, Universidade do Porto, for help in identification of plant species. 


\section{References}

APHA, 1998. Standard Methods for the Examination of Water and Wastewater, twentieth ed. American Public Health Association/American Water Works Association/Water Environment Federation, Washington DC, USA.

Baptista, J.D.C., Donnelley, T., Rayne, D., Davenport, R.J., 2003. Microbial mechanisms of carbon removal in subsurface flow wetlands. Water Sci. Technol. 48 (5), 127-134.

Brix, H., 1994. Functions of macrophytes in constructed wetlands. Water Sci. Technol. 29 (4), 71-78.

Brix, H., 1997. Do macrophytes play a role in constructed treatment wetlands? Water Sci. Technol. 35 (5), 11-17.

Daniels, R., 1998. You're now entering the root zone-investigation: the potential of reed beds for treating waste waters from leather manufacture. World Leather 11 (7), 48-50.

Daniels, R., 2001a. Enter the root-zone: green technology for the leather manufacturer, part 1. World Leather 14 (4), 63-67.

Daniels, R., 2001b. Enter the root-zone: green technology for the leather manufacturer, part 3. World Leather 14 (6), 85-88.

García, J., Aguirre, P., Barragán, J., Mujeriego, R., Matamoros, V., Bayona, J.M., 2005. Effect of key design parameters on the efficiency of horizontal subsurface flow constructed wetlands. Ecol. Eng. 25, 405-418.

García, J., Aguirre, P., Mujeriego, R., Huang, Y., Ortiz, L., Bayona, J.M., 2004. Initial contaminant removal performance factors in horizontal flow reed beds used for treating urban wastewater. Water Res. 38, 1669-1678.

Houba, V.J.G., Van Der Lee, J.J., Novozamsky, I., 1995. Soil Analysis Procedures-Other Procedures (Soil and Plant Analysis, part 5B). Department of Soil Science and Plant Nutrition, sixth ed. Wageningen Agricultural University Syllabus, Wageningen, The Netherlands.

Huang, J., Reneau, J.R.R.B., Hagedorn, C., 2000. Nitrogen removal in constructed wetlands employed to treat domestic wastewater. Water Res. 34 (9), 2582-2588.

Jett, J.W., 2005. Plant pH preferences. West Virginia University Extension Service, USA.

Kadlec, R.H., Knight, R.L., Vymazal, J., Brix, H., Cooper, P., Haberl, R., 2000. Constructed wetlands for pollution control-processes, performance, design and operation. IWA Scientific and Technical Report No. 8. IWA Publishing, London, UK.

Klomjek, P., Nitisoravut, S., 2005. Constructed treatment wetland: a study of eight plant species under saline conditions. Chemosphere 58, 585-593.

Korkusuz, E.A., 2005. Manual of Practice on Constructed Wetlands for Wastewater Treatment and Reuse in Mediterranean Countries. Report, MED-REUNET II Support Programme (EC Project No: INCO-CT-2003-502453), AGBAR FOUNDATION, Spain. 〈http://med-reunet.org// $\rangle$.

Kucuk, O.S., Sengul, F., Kapdan, I.K., 2003. Removal of ammonia from tannery effluents in a reed bed constructed wetland. Water Sci. Technol. 48 (11-12), 179-186.
Mæhlum, T., Stålnacke, P., 1999. Removal efficiency of three coldclimate constructed wetlands treating domestic wastewater: effects of temperature, seasons, loading rates and input concentrations. Water Sci. Technol. 40 (3), 273-281.

Maine, M.A., Suñe, N., Hadad, H., Sánchez, G., Bonetto, C., 2006. Nutrient and metal removal in a constructed wetland for wastewater treatment from a metallurgic industry. Ecol. Eng. 26, 341-347.

Mantovi, P., Marmiroli, M., Maestri, E., Tagliavini, S., Piccinini, S., Marmiroli, N., 2003. Application of a horizontal subsurface flow constructed wetland on treatment of dairy parlor wastewater. Bioresour. Technol. 88, 85-94.

Mbuligwe, S.E., 2005. Comparative treatment of dye-rich wastewater in engineered wetland systems (EWSs) vegetated with different plants. Water Res. 39, 271-280.

Metcalf and Eddy,Inc., 1991. In: Tchobanoglous, G., Burton, F.L. (revisors), Wastewater Engineering: Treatment, Disposal and Reuse, third edition. McGraw-Hill Publishing, NY, USA.

Oliveira, R.S., Dodd, J.C., Castro, P.M.L., 2001. The mycorrhizal status of Phragmites australis in several polluted soils and sediments of an industrialised region of Northern Portugal. Mycorrhiza 10, 241-247.

Shepherd, H.L., Grismer, M.E., Tchobanoglous, G., 2001. Treatment of high-strength winery wastewater using a subsurface-flow constructed wetland. Water Environ. Res. 73 (4), 394-403.

Smith, J., Valenzuela, H., 2002. Sustainable Agriculture Cover Crops: St. Augustinegrass Fact Sheet; College of Tropical Agriculture and Human Resources, University of Hawai'i at Manoa; Hawaii, USA; CTAHR-Aug., SA-CC-4.

Song, Z., Williams, C.J., Edyvean, R.G.J., 2000. Sedimentation of tannery wastewater. Water Res. 34 (7), 2171-2176.

Tanner, C.C., 2001. Plants as ecosystem engineers in subsurfaceflow treatment wetlands. Water Sci. Technol. 44 (11-12), 9-17.

USEPA (2000a). A Handbook of Constructed Wetlands, A Guide to Creating Wetlands for: Agricultural Wastewater, Domestic Wastewater, Coal Mine Drainage, Stormwater in the MidAtlantic Region.--Volume 1: General Considerations. United Sates Environmental Protection Agency, Washington DC, New York, USA.

USEPA (2000b). Wastewater Technology Fact Sheet-Wetlands: Subsurface Flow. EPA 832-F-00-023. United Sates Environmental Protection Agency, Washington DC, New York, USA.

Vrhovšek, D., Kukanja, V., Bulc, T., 1996. Constructed wetland (CW) for industrial waste waster treatment. Water Res. 30 (10), 2287-2292.

Vymazal, J., 2005. Horizontal sub-surface flow and hybrid constructed wetlands systems for wastewater treatment. Ecol. Eng. 25, 478-490.

Vymazal, J., Kröpfelová, L., 2005. Growth of Phragmites australis and Phalaris arundinacea in constructed wetlands for wastewater treatment in the Czech Republic. Ecol. Eng. 25, 606-621. 